\title{
MODELO DE TOMADA DE DECISÃO PARA USO DE PROFESSORES DO ENSINO FUNDAMENTAL NA IDENTIFICAÇÃO DE AUTISMO E DEFICIÊNCIA INTELECTUAL1
}

\author{
DECISION-MAKING MODEL FOR ELEMENTARY SCHOOL TEACHERS \\ TO IDENTIFY AUTISM AND INTELLECTUAL DISABILITY
}

\section{MODELO DE TOMA DE DECISIÓN PARA USO DE MAESTROS DE EDUCACIÓN PRIMARIA EN LA IDENTIFICACIÓN DEL AUTISMO Y LA DISCAPACIDAD INTELECTUAL}

\author{
Maria Cristina Triguero Veloz Teixeira ${ }^{2}$, Luiz Renato Rodrigues Carreiro ${ }^{3}$, Alessandra Gotuzo \\ Seabra ${ }^{4}$, Leandro Augusto da Silva ${ }^{5}$, Ana Claudia Rossi ${ }^{6}$, Tally Lichtensztejn Tafla ${ }^{7}$, Erick \\ Fernando Doria Lopes $^{8}$, Decio Brunoni ${ }^{9}$
}

\section{RESUMO}

Ainda há um número significativo de alunos que ingressam no ensino fundamental com transtornos do neurodesenvolvimento, como o Transtorno do Espectro Autista (TEA) e a Deficiência Intelectual (DI), sem diagnóstico garantindo seus direitos legais aos Serviços Educacionais Especiais (SES). De acordo com o sistema público de saúde brasileiro (SUS), a identificação precoce e o monitoramento do TEA devem ser realizados pelas equipes de saúde e educação. O objetivo deste estudo foi desenvolver um modelo de tomada de decisão, com um fluxograma detalhando tarefas e ações, utilizado por professores do ensino fundamental do sistema público de ensino com instrumentos para avaliação de indicadores de TEA e DI. O estudo foi realizado em duas fases. Fase 1: Dois instrumentos em um formato de checklist de verificação foram produzidos contendo descrições sobre as características dos transtornos para auxiliar o professor na avaliação dos alunos. Fase 2: Dois

\footnotetext{
${ }^{1}$ This study was financed by the Coordenação de Aperfeiçoamento de Pessoal de Nível Superior - Brasil (CAPES/ Master-Fellowship), by the Fundação de Amparo à Pesquisa do Estado de São Paulo (FAPESP/ Finance Code 2018/01063-0) and by the Conselho Nacional de Desenvolvimento Científico e Tecnológico (CNPq/ Finance Code 408808/2016-0).

${ }^{2}$ Doutora em Filosofia da Saúde - Universidade Federal de Santa Catarina (UFSC) - Florianópolis, SC -Brasil. Docente - Universidade Presbiteriana Mackenzie (UPM) - São Paulo, SP - Brasil. E-mail: mctvteixeira@gmail.com.

${ }^{3}$ Doutor em Ciências - Universidade de São Paulo (USP) - São Paulo, SP - Brasil. Docente - Universidade Presbiteriana Mackenzie (UPM) - São Paulo, SP - Brasil. E-mail: renato.carreiro@gmail.com.

${ }^{4}$ Doutora em Psicologia - Universidade de São Paulo (USP) - São Paulo, SP - Brasil. Docente - Universidade Presbiteriana Mackenzie (UPM) - São Paulo, SP - Brasil. E-mail: alessandragseabra@gmail.com.

${ }^{5}$ Doutor em Engenharia Elétrica - Universidade de São Paulo (USP) - São Paulo, SP - Brasil. Docente Universidade Presbiteriana Mackenzie (UPM) - São Paulo, SP - Brasil. E-mail: prof.leandro.augusto@gmail.com. ${ }^{6}$ Mestre em Engenharia Elétrica - Universidade de São Paulo (USP) - São Paulo, SP- Brasil. Docente Universidade Presbiteriana Mackenzie (UPM) - São Paulo, SP - Brasil. E-mail: anaclaudia.rossi@mackenzie.br. ${ }^{7}$ Mestre em Distúrbios do Desenvolvimento - Universidade Presbiteriana Mackenzie (UPM) - São Paulo, SP Brasil. Doutoranda em Distúrbios do Desenvolvimento Universidade Presbiteriana Mackenzie (UPM) - São Paulo, SP - Brasil. E-mail: tafla.tally@gmail.com.

${ }^{8}$ Graduando em Ciência da Computação - Universidade Presbiteriana Mackenzie (UPM) - São Paulo, SP - Brasil. E-mail: ericklopes1998@hotmail.com.

${ }^{9}$ Doutor em Ciências Biológicas - Universidade Federal do Rio de Janeiro (UFRJ), Rio de Janeiro, RJ - Brasil. Docente - Universidade Presbiteriana Mackenzie (UPM) - São Paulo, SP - Brasil. E-mail: debruno46@gmail.com.
}

Submetido em: 29/05/2019 - Aceito em: 28/12/2019

(C) ETD-Educação Temática Digital Campinas, SP $\quad$ v.22 n.1 $\quad$ p.106-126 jan./mar.2020


fluxogramas foram criados, um para cada transtorno, composto por um conjunto de atividades sequenciais logicamente organizadas. O procedimento para os fluxogramas consistiu em um processo baseado no Business Process Model and Notation (BPMN), utilizando a plataforma de código aberto Business Process Management System (BPMS). O relatório final permite a visualização dos resultados da avaliação, como indicadores do checklist, avaliação neuropsicológica, avaliações emocionais e comportamentais. O estudo apresenta um modelo de processo para professores e gestores educacionais que utiliza um sistema computadorizado para auxiliá-los na coleta e análise de dados, bem como a tomada de decisão em tempo real para identificar alunos com suspeita de transtornos do neurodesenvolvimento.

PALAVRAS-CHAVE: Educação Básica; Deficiência Intelectual; Autismo; Ambiente Big Data.

\section{ABSTRACT}

There are still a significant number of students who enter the elementary school with neurodevelopmental disorders, such as Autism Spectrum Disorder (ASD) and Intellectual Disability (ID), without having a diagnosis that guarantees their legal rights to Special Educational Services (SES). According to the Brazilian public health system (SUS), early identification and monitoring of ASD should be carried out by both the health and education teams. The objective of this study was to develop a decision-making model, with a flowchart detailing the required tasks and actions, through the use by elementary education teachers in the public education system of instruments for the evaluation of indicators of ASD and ID. The study was conducted in two phases. Phase 1: Two instruments in a checklist format were produced containing statements about the characteristics of the disorders to assist the teacher in the evaluation of students. Phase 2: Two flowcharts were created, one for each disorder, composed of a set of logically organized sequential activities. The procedure for both flowcharts consisted of a process based on Business Process Model and Notation (BPMN), using the opensource platform Business Process Management System (BPMS). The final report allows the visualization of the results from the evaluation, such as checklist's indicators, neuropsychological assessment, emotional and behavioral assessments. The study presents a process model for teachers and educational managers that uses a computer system to assist them in the collection and analysis of data, as well as decision-making in real time to identify students with suspected neurodevelopmental disorders.

KEYWORDS: Basic education; Intellectual Disability; Autism; Big Data environment.

\section{RESUMEN}

Todavía hay un número significativo de estudiantes que ingresan a la escuela primaria con trastornos del neurodesarrollo, como el Trastorno del Espectro del Autismo (TEA) y la Discapacidade Intelectual (DI), sin tener un diagnóstico que garantice sus derechos legales a los Servicios de Educación Especial (SES). De acuerdo con el Sistema de Salud Pública (SUS) de Brasil, tanto el equipo de salud como de educación deben llevar a cabo la identificación y el monitoreo tempranos del TEA. El objetivo de este estudio fue desarrollar un modelo para tomar decisión, con un diagrama de flujo que detalla las tareas y acciones requeridas, através del uso por parte de los maestros de educación primaria del sistema de educación pública de instrumentos para la evaluación de indicadores de TEA e DI. El estudio se realizó en dos fases. Fase 1: Se produjeron dos instrumentos en formato de lista de verificación que contiene descripciones de características de los trastornos para ayudar al maestro en la evaluación de los estudiantes. Fase 2: se crearon dos diagramas de flujo, uno para cada trastorno, compuesto por un conjunto de actividades secuenciales organizadas logicamente. El procedimiento para ambos diagramas de flujo consistió en un proceso basado en el Modelo de Proceso de Negocio y la Notación (BPMN), utilizando el sistema de gestión de procesos de negocio (BPMS) de plataforma de código abierto. El informe final permite la visualización de resultados de la evaluación, como indicadores de la lista de verificación, evaluación neuropsicológica y evaluaciones emocionales y de comportamiento. El estudio presenta un modelo de proceso para maestros y administradores educativos que utiliza un sistema informático para ayudarlos en la recopilación y análisis de datos, así como la toma de decisiones en tiempo real para identificar los estudiantes con sospechas de trastornos del neurodesarrollo.

PALAVRAS-CLAVE: Educación básica; Discapacidad Intelectual; Autismo; Ambiente Big Data.

(C) ETD- Educação Temática Digital Campinas, SP v.22 n.1 $\quad$ p.106-126 jan./mar.2020




\section{INTRODUCTION}

The compulsory requirement for Special Educational Services (SES) in Brazil has resulted in an increased number of special education target students enrolled in Brazilian schools (BRASIL, 2008). A survey by thb e Ministry of Education (BRASIL, 2016a), aimed at monitoring the inclusion process, showed an increase in the enrollment of this type of student from 504,039 in 2003 to 930,683 in 2015, representing an increase of $85 \%$. The enrollment rates of special education target students in mainstream education classes also showed a significant increase, from 145,141 students in 2003 to 760,983 in 2015, an increase of 425\% (BRASIL, 2016a).

However, there are still a significant number of students who enter the first phase of elementary school with neurodevelopmental disorders, such as autism spectrum disorder (ASD) and intellectual disability (ID), without having a diagnosis that guarantees their legal rights to SES (ROBERTSON et al., 2012).

Intellectual disability is manifested by different levels of intellectual impairment with limitations in social and adaptive functioning. In its intellectual aspects, it is characterized by deficits in reasoning, problem solving, planning, abstract thinking, judgment and academic learning. In social functioning, limitations can be observed in skills for the recognition of the feelings and experiences of others, empathy, interpersonal communication and social judgment, among others (APA, 2014; TEIXEIRA et al., 2017a). Impairments in adaptive functioning manifest themselves as deficits in the skills and abilities to perform daily living activities, both from a practical and social point of view. In respect of the practical aspects, individuals can present mild to severe limitations in learning, self-management in various contexts such as personal care, self-control and task organization, among others. In 2011, Maulik and colleagues published a systematic review study of ID prevalence rates based on 52 studies. The prevalence rates of ID according to age were 4.9:1000 (for the adult population); 18.30:1000 (for children and adolescents) and 5.04:1000 (for the combined adult, child and adolescent population), with the highest rates being in poor and developing countries (MAULIK et al., 2011). The Diagnostic and Statistical Manual of Mental Disorders/DSM - 5 (APA, 2014) stated that the prevalence rates of ID were about $1 \%$ of the general population, with variations due to age, specifying a rate of about 6:1000 for severe ID (APA, 2014). In Brazil, a study by Malta and colleagues (2016)assessed the epidemiological distribution of various types of disabilities, ID being one of these (reporting an ID prevalence rate of $0.8 \%$ in the surveyed areas, with no differences by age, ethnicity and region). Although the study by Malta and colleagues (2016) represented an important advance to support decisions taken in respect of public policy formation to care for this population, the data collection technique was based on interviews with caregivers, without the use of standardized instruments, which resulted in methodological limitations. In contrast, a study conducted in southern Brazil with 4231 participants used

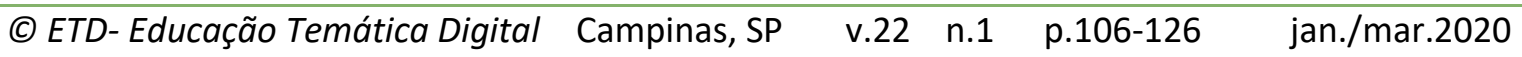


intelligence tests and evaluated developmental milestones, reporting ID prevalence rates of $4.5 \%$ in the studied population (KARAM et al., 2015). However, it should be noted that the study by Karam and colleagues, while having excellent genetic and developmental assessments with repeated measures, did not evaluate the other two domains (social and practical) that are recommended for the diagnosis of ID according to DSM-5 (APA, 2014), which may explain the higher prevalence values in this study.

ASD, on the other hand, is a highly variable disorder throughout the different stages of development, characterized by signs and symptoms manifested in deficits in interaction and social communication, as well as the presence of restricted and repetitive patterns of behaviors, interests and activities. In general, the impairment can be observed as difficulties in social-emotional exchanges, verbal and non-verbal communication, the establishment of social relations, stereotypies and ritualized behaviors, inflexibility, and sensorial alterations, among others (APA, 2014; PAULA et al., 2017). One of the most recent estimates of prevalence rates of the disorder by Christensen et al. (2016) estimated a rate of 1:69 in children in a population study conducted in 11 cities in the United States. In 2018, a new study by the same author found that ID rates in 8-year-old children with ASD in 9 of these cities ranged from $20 \%$ (in Utah) to $48 \%$ (Arkansas) (BAIO et al., 2018). A Brazilian epidemiological study of 2015 estimated that the rate of ASD is around 1\% (PARASMO et al., 2015).

As ASD and ID often appear early in a child's development, have a chronic course, and multiple etiologic factors associated with high variability, Brazilian public policies recommend that the diagnosis be made in the first years of life (BRASIL, 2016b). As a result of these policies, the diagnosis of ASD at early ages of development has been more frequent, however, there are still some regional imbalances between different areas of the country (BRASIL, 2007, BRASIL, 2014, PORTOLESE et al., 2017). These imbalances are associated with different factors, such as a lack of training of health professionals and a shortage of specialized services (COUTO et al., 2008; SANTOS \& FERNANDEZ, 2014; BORDINI et al., 2015; SANTOS \& CELERI, 2018); delays in parents detecting the first signs of autism that in turn delays the search for professional help and receiving the diagnosis (ZANON et al., 2014; OLASHORE et al., 2017); and the long waiting times for diagnostic evaluations in specialized child mental health services (ARAUJO \& TANAKA, 2012), among others. The diagnosis of ID in early life has not received the same attention as ASD in terms of studies that assess the factors associated with the delay in its identification (RUSSELL et al., 2019).

In Brazil, as in other developing countries (OLASHORE et al., 2017), there are few public policies that establish mandatory screening to detect indicators of neurodevelopmental changes in children, either through mental health services or the public education system (BORDINI et al., 2015; COUTO \& DELGADO, 2015; PAULA et al., 2016; BOSA \& TEIXEIRA, 2017; TEIXEIRA et al., 2017; PAULA et al., 2018; FARIA et al., 2018). This lack of monitoring of mental health problems in childhood, combined with the clinical complexity of

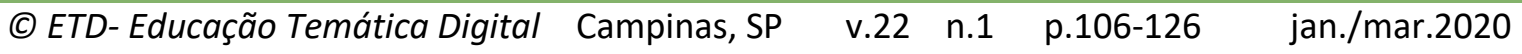


these disorders, causes a high number of children with ASD or ID to start elementary school without having received the due diagnosis (ROBERTSON et al., 2012; ZANON et al., 2014; LAKHAN \& MAWSON, 2016; DENCKLA et al., 2017; FRANZ et al., 2017; TEIXEIRA et al., 2017).

When a student with ASD or ID is enrolled in the first phase of elementary school without yet being diagnosed, teachers can be one of the main actors to identify these students. Moreover, according to the monitoring and care flowchart for people with ASD in the Brazilian public health system (SUS), early identification and monitoring of ASD should be carried out by both the health and education teams (in this case, by the classroom teacher) (BRASIL, 2014). However, raising suspicions of disorders such as these demands specific training, both in relation to expected developmental milestones and signs and symptoms, as well as in the use of appropriate instruments that allow the professional to perform a careful evaluation of the student suspected to have ASD or ID. A study by Murphy et al. (2015) found that the use of standardized instruments for mental health evaluation by teachers can be useful in identifying students who might benefit from preventive and/or remedial interventions. When the teacher identifies a child who may have one of the conditions, those responsible for the child can be conducted to diagnostic evaluations. Giving teachers both the correct training and evaluation tools, could contribute to a more efficient use of public resources and enable interventions and care for children with ASD or ID.

Currently equipping professionals to use evaluation tools has significantly benefited from computer systems for collecting and analyzing data with applications in sectors such as economics, education and health (TURBAN et al., 2010; SILBERSCHAATZ et al., 2006). Elementary education is an appropriate setting for the implementation of this type of technology, since it can assist in the collection, storage, monitoring and analysis of data of students enrolled in the public education system. Among these computer systems, database management systems (DBMS) have had the most significant growth, both in respect of their storage and data mining capabilities (SILVA, PERES \& BOSCARIOLI, 2016). These systems function as a resource for the creation of repositories of data or actions and, as a result, can be sources for data analysis focused on generating managerial reports for tracking or monitoring tasks and actions in diverse areas of knowledge.

There were three main reasons for this study: a) the need to equip teachers, both in respect of training and the use of assessment tools for students with suspected ASD and ID who enter the first stage of elementary school in Brazil; b) the need to optimize the assessment processes conducted by teachers; c) the application of computer systems in order to assist the registration and storage of data to monitor tasks and actions and to systematize decision-making regarding referrals of students to other public services (MAYERSCHÖNBERGER \& CUKIER, 2013).

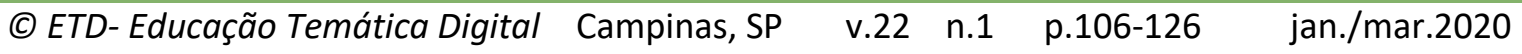


Based on these goals, the overall objective of this study was to develop a decisionmaking model, with a flowchart detailing the required tasks and actions, through the use by elementary education teachers in the public education system of instruments for the evaluation of indicators of ASD and ID. The specific objectives of the study were: a) to construct two evaluation checklists for students with suspected ID and ASD, based on DSM-5 clinical criteria for the use of teachers in elementary school; b) to assess the construct validity of these instruments based on the analysis of experts; c ) delimit the tasks and actions that each actor of the process should have, including producing guidelines on the specialized evaluations that should take place following the evaluations made by the teachers; d) develop a computer system to implement flowcharts with actions, activities and decisions to identify elementary school students suspected of having ID, ASD or both conditions.

\section{METHOD}

The study was conducted in two phases.

\section{Phase 1}

Two instruments in a checklist format were produced containing statements (called items) about the characteristics of the disorders to assist the teacher in the evaluation of students suspected of having ASD or ID. Response options were on a Likert scale of the frequency with which the items can be observed in the student by the teacher ('never or rarely', 'sometimes', 'often' or 'very often').

The construct validity of the instruments was then assessed by 6 experts selected based on their backgrounds, experience and knowledge of the subject. All had a PhD in the area of human development, as well as clinical and teaching experience in the same area. The criteria used for the analysis were objectivity, clarity and precision as described by Pasquali (2010). The definitions adopted for the criteria were: objectivity, the item is adequately described for its correct application or scoring; clarity, the item is clear and comprehensible for its application and scoring by teachers; precision, the item is specific and precise in what it describes or evaluates in relation to the activity/behavior/area in question and not to others.

Each instrument was evaluated by 3 of the experts and scored on a scale of 0 to 2 (response 0 indicated total disagreement as to clarity, accuracy or objectivity; response 1 indicated partial agreement; response 2 indicated total agreement). The experts' average scores for each criterion were calculated for all items of the instrument (PASQUALI, 2010). The experts were asked to propose changes to the items to match their wording to the evaluated criteria. 
The results were analysed by their average score in respect of meeting the criterion, and there was also a qualitative analysis of the suggestions made by the experts. These analyses, described in the results section, enabled the writing of the final versions of the two checklists.

\section{Phase 2}

Two flowcharts were created, one for ASD and the other for ID. Both were composed of a set of logically organized sequential activities, in line with the objectives of the study. In each activity the tasks of the teacher and of the SES team of the educational system were defined. The main purpose of the flowcharts was to represent schematically an operational sequence of actions that can be developed within their own educational system, the main actors being the classroom teachers, the SES team and network managers. In these flowcharts, the processes start with the checklists developed in phase 1. To complement this initial assessment by the teacher's specific evaluation instruments for ASD and ID to be applied by the teachers or the SES team of a given educational system, including psychologists, were selected. The results will be described in the results and discussion section.

After the completion of the flowcharts, the actions of the flowcharts were computerized in order to optimize their use and provide real-time monitoring in the public education system. The procedure for both flowcharts consisted of a process for identifying cases of the disorders based on Business Process Model and Notation (BPMN) and automated using the open-source platform Business Process Management System (BPMS), BonitaSoft (DAMIJ \& DAMIJ, 2013). The software can be applied in any educational system, regardless of the number of students enrolled. The BPMS BonitaSoft platform consists of Bonita BPM Studio (a module for business process modeling), UI Designer (a module for creating web pages defined in HTML for human interaction, which uses web development languages such as Javascript, AngularJs, BootStrap and others), and an e-mail module. In addition, the BonitaSoft platform allows connections to other platforms including databases such as MySql, SQL Server, Oracle and PostgreSQL. Thus, through the BonitaSoft platform it was possible to develop a BPMS web portal to identify possible cases of the disorders, via a Web server that can be accessed through the Internet by all those involved in the educational system.

BPMS works through of a sequence of activities from the beginning to the end and can be deployed in a network such as the computers of schools that are part of a particular municipality. The logic of the process is visually demonstrated by a flowchart created by the connected sequences that comprise all the activities that must be developed and their respective agents. The purpose of transferring these flowcharts to this BPMS model was to offer the educational system the ability to manage the evaluations, record data and monitor the process, - from the initial identification of the student by the teacher until the

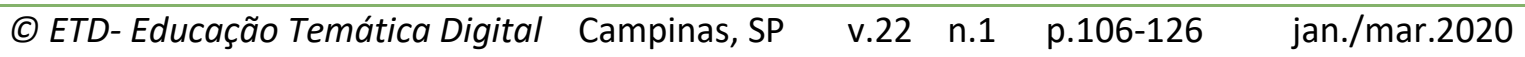


confirmation of the suspected condition. It could also be used in the final stage of the process when the student is referred to the mental health services of the locality with the report being made to the educational system through the system. All flow-chart decisions were based on evidence-based instruments that meet the DSM-5 clinical criteria for both disorders (Table 1).

Another procedure that should be adopted in this phase to ensure the successful implementation of the flowchart in an educational system is that teachers, and members of the SES team should be trained in the expected cognitive, behavioral and functional milestones in child development, as well as in the signs of the neurodevelopmental disorders involved in the project (ASD and ID). They should also receive training in the process model, in relation to all phases of the respective flowcharts of procedures and evaluation instruments to define suspected ASD and ID. Depending the role of each one of the professionals in the process, they should also receive training and specific orientation in the use of the instruments and their role in the computer system. Training in the use of the flowcharts in the BPMS system should be offered in a computer environment to ensure that the teachers and other professionals who are the main actors in the use of these tools have the required skills and competencies to use them effectively. To achieve this, an instruction manual for the system has been developed, and can be accessed (on request to the authors) at the following link: http://Ifs.mackenzie.br/bonita/. The system can only be put into use in an educational system after the specific training described here has been completed. Following the results of a pilot study by Suriano (2018), it is recommended that the assessments detailed in the flowcharts are only carried out 4 months after the start of the school year, so that the teachers are able to build up knowledge about their students' problems.

The last activity in the flowcharts should be performed by local mental health professionals and targets the evaluation to confirm or not confirm the diagnosis of ASD or ID, with appropriate recommendations or interventions according to each outcome. Connections were designed in the flowchart to indicate the desired collaboration that should exist between health and education systems in treating children with neurodevelopmental disorders. 


\section{RESULTS AND DISCUSSION}

\section{Phase 1}

The results of the analysis of construct validity are shown in Table 1 . The lowest averages were obtained in the instrument to evaluate the presence of ID in the criteria of clarity and precision. The agreement indexes among the experts in respect of these criteria was also the lowest. The suggested amendments of the experts were included in the items with the aim of producing an instrument whose items had adequate precision, clarity and objectivity according to the type of construct validity adopted. Appendix A and B show the final versions of the two instruments.

Table 1. Agreement indexes of the construct validity analysis of the instruments (criteria of accuracy, precision and clarity).

\begin{tabular}{|c|c|c|}
\hline $\begin{array}{l}\text { Suspected } \\
\text { Disorder }\end{array}$ & $\begin{array}{l}\text { Suspected Autism Spectrum Disorder } \\
\text { screening checklist }\end{array}$ & $\begin{array}{l}\text { Suspected Intellectual Disability } \\
\text { screening checklist }\end{array}$ \\
\hline Criteria & $\begin{array}{l}\text { Average of agreement indexes } \\
\text { between experts }\end{array}$ & $\begin{array}{l}\text { Average of agreement indexes } \\
\text { between experts }\end{array}$ \\
\hline Objectivity & 1.95 & 1.90 \\
\hline Clarity & 1.80 & 1.70 \\
\hline Accuracy & 1.82 & 1.70 \\
\hline
\end{tabular}

Appendix A. Suspected Autism Spectrum Disorder screening checklist.

Appendix B. Suspected Intellectual Disability screening checklist.

\section{Phase 2}

Flowcharts of the actions, activities and decision-making were designed for elementary students with a suspected neurodevelopmental disorder related to ID, or ASD or with both disorders. They are shown in Figures 1 and 2.

Figure 1. Flowchart of activities and decision-making to identify students with suspected Autism Spectrum Disorder. 


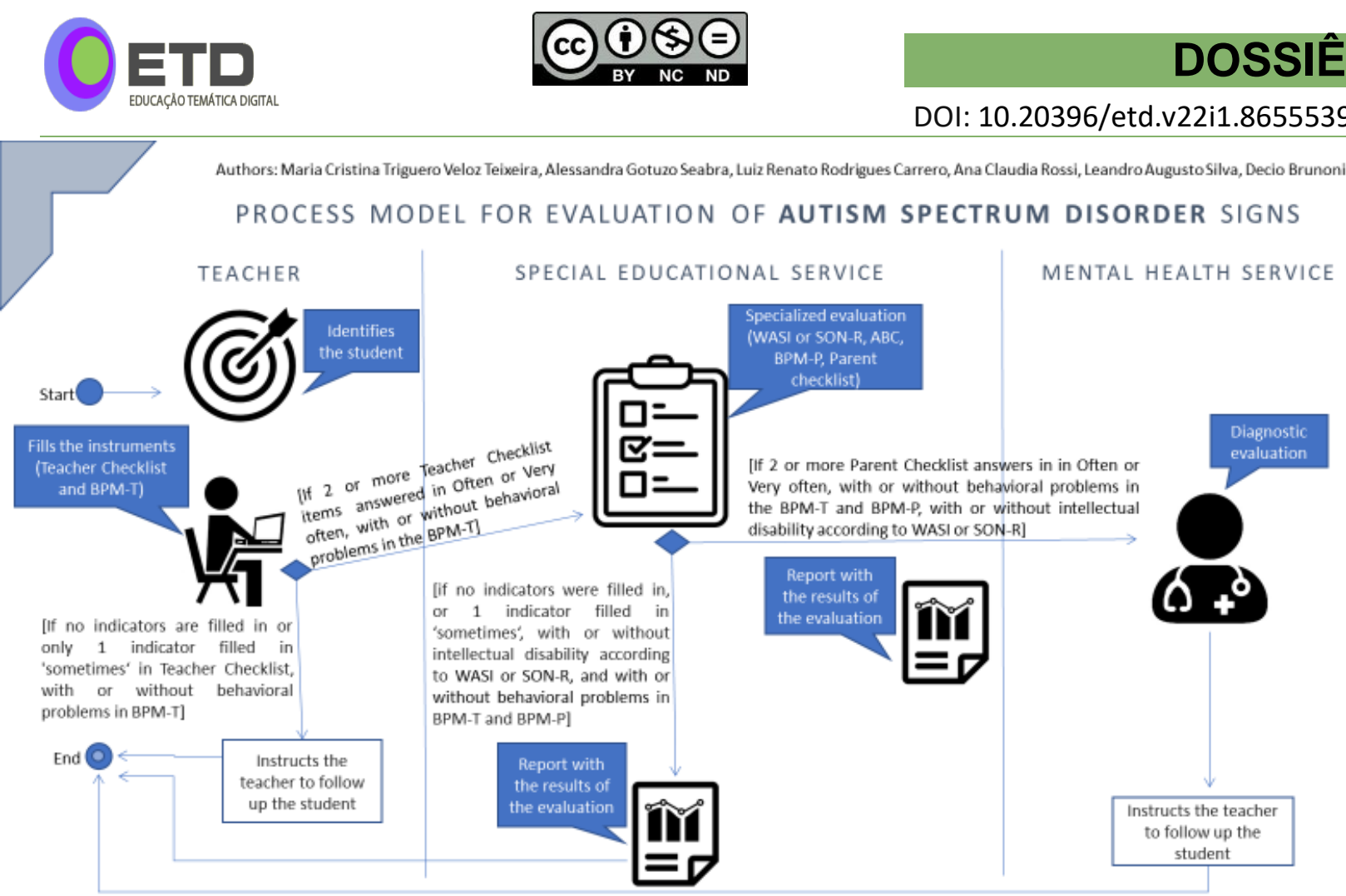

Figure 2. Flowchart of activities and decision-making to identify students with suspected Intellectual Disability.

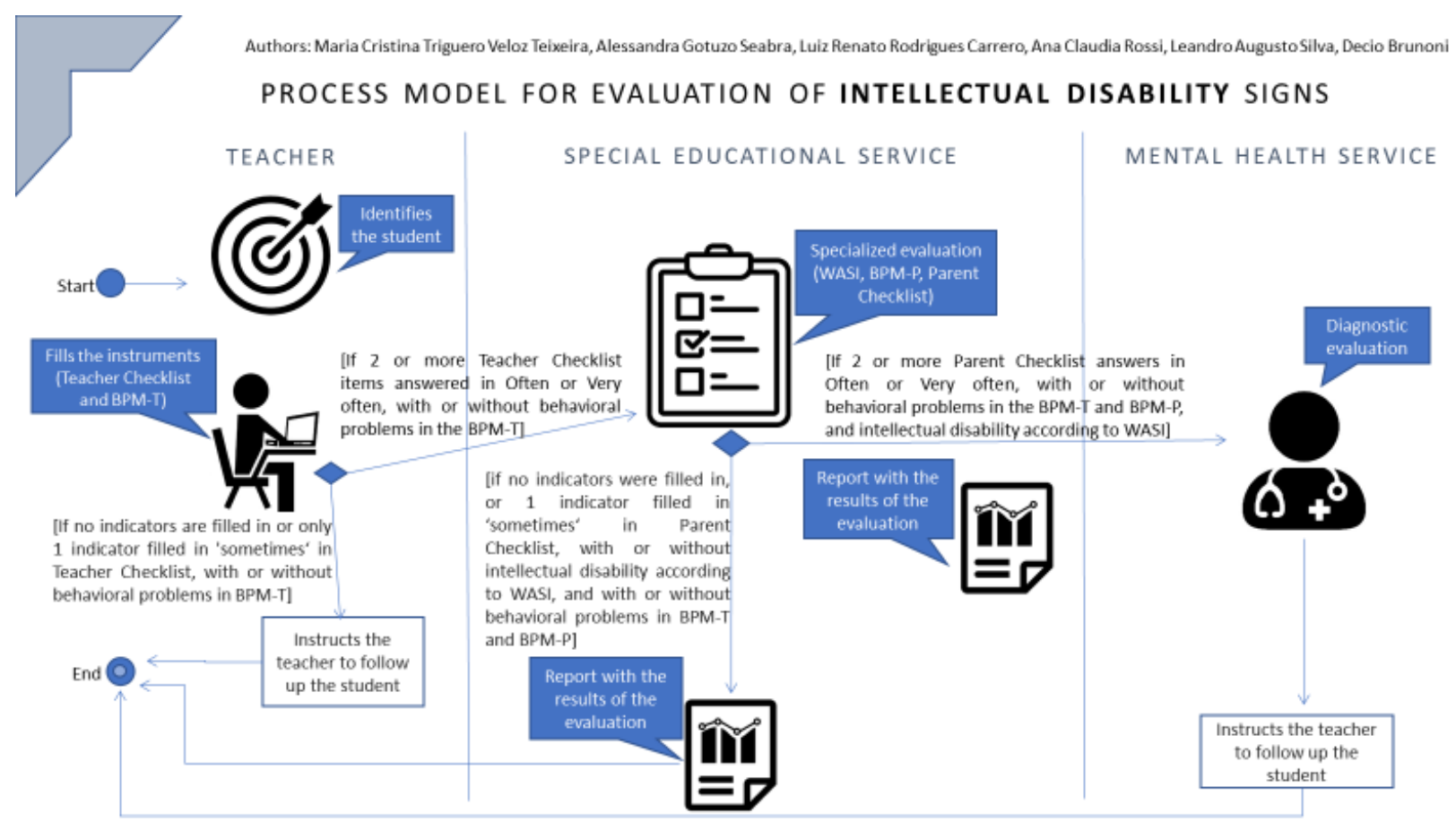

Figures 1 and 2 show that the process begins with the identification by the teacher of students with signs and/or suspected symptoms ASD or ID. After the identification of the student, the teacher completes the checklists on the characteristics of the disorders (Figures

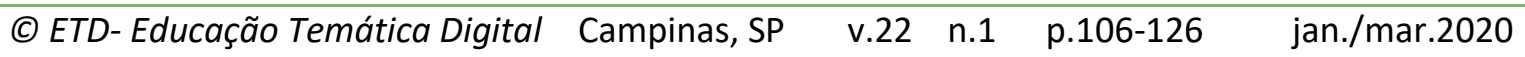


1 and 2 ) and the BPM-T (see BPM-T in Chart 1) for an emotional and behavioral assessment. If the student presents both complaints, the teacher can complete the two checklists.

The first decision is then made based on the results in the checklists for each type of complaint (see Figures 1 and 2). The student remains in the evaluation process if at least one of the responses to the items on the checklist is "sometimes", "often", or "very often.

The tools provided in the flowcharts (Figures 1 and 2) for use by the teacher or the SES staff team (which must include a psychologist, since some of these instruments are restricted for use by these professionals) are shown in Chart 1 . They were selected after an analysis of the instruments available for use in Brazil compatible with the characteristics of each disorder and with the purpose of the process model. 
Table 1. Specific assessment instruments for Autism Spectrum Disorder and Intellectual Disability.

\begin{tabular}{|c|c|c|c|}
\hline $\begin{array}{l}\text { Suspected } \\
\text { Condition }\end{array}$ & Instrument & Goals & Applied By \\
\hline \multirow[b]{2}{*}{$\begin{array}{l}\text { Autism } \\
\text { Spectrum } \\
\text { Disorder and } \\
\text { Intellectual } \\
\text { Disability }\end{array}$} & $\begin{array}{l}\text { Wechsler } \\
\text { Abbreviated Scale } \\
\text { of Intelligence } \\
\text { (WASI) (YATES et } \\
\text { al., 2006). }\end{array}$ & $\begin{array}{l}\text { Evaluates } \\
\text { functioning of individuals from } 6 \text { to } \\
89 \text { years The WASI consists of four } \\
\text { subtests: Vocabulary and Similarities } \\
\text { form the Verbal Intelligence Quotient } \\
\text { (VIQ) while Block Design and Matrix } \\
\text { Reasoning form the Performance } \\
\text { Intelligence Quotient (PIQ). In } \\
\text { addition, all four subtests are } \\
\text { combined to form the Full-Scale IQ-4 } \\
\text { Subtests. }\end{array}$ & $\begin{array}{l}\text { Must be applied by a } \\
\text { Psychologist. }\end{array}$ \\
\hline & $\begin{array}{l}\text { Brief Problem } \\
\text { Monitor (BPM) } \\
\text { (Brief Problem } \\
\text { Monitor - Teacher } \\
\text { Form For Ages 6- } \\
\text { 18/BPM-T } \\
\text { and (Brief Problem } \\
\text { Monitor - Parent } \\
\text { Form For Ages 6- } \\
\text { 18/BPM-P] } \\
\text { (ACHENBACH \& } \\
\text { RESCORLA, 2001). }\end{array}$ & $\begin{array}{l}\text { Assesses emotional and behavioral } \\
\text { problems, both internalizing and } \\
\text { externalizing types and attention } \\
\text { problems in children and adolescents } \\
\text { between } 6 \text { and } 18 \text { years. BPM-P and } \\
\text { BPM-T are short-form versions of Child } \\
\text { Behavior Checklist For Ages 6-18/CBCL } \\
\text { and Teacher's Report Form For Ages 6- } \\
\text { 18/TRF, respectively. }\end{array}$ & $\begin{array}{l}\text { BPM-T must be completed } \\
\text { by the student's class } \\
\text { teacher. } \\
\text { BPM-P should be completed } \\
\text { by the parents or caregivers } \\
\text { of the child and may be } \\
\text { applied by any SES team } \\
\text { professional with specific } \\
\text { training in the use of the } \\
\text { instrument. }\end{array}$ \\
\hline \multirow{2}{*}{$\begin{array}{l}\text { Autistic } \\
\text { Spectrum } \\
\text { Disorder }\end{array}$} & $\begin{array}{l}\text { Autism Behavior } \\
\text { Checklist } \\
\text { (MARTELETO \& } \\
\text { PEDROMÔNICO, } \\
\text { 2005). }\end{array}$ & $\begin{array}{l}\text { The Autism Behavior Checklist (ABC) } \\
\text { consists of a list of atypical behaviors } \\
\text { characteristic of the Autism and is } \\
\text { designed for the screening of children } \\
\text { suspected of having this disorder. The } \\
\text { ABC is composed of } 57 \text { atypical } \\
\text { behaviors related to five areas: 1) } \\
\text { sensory stimuli sensorial; } 2 \text { ) relating; 3) } \\
\text { body and object use; 4) language; and 5) } \\
\text { social self-care. }\end{array}$ & $\begin{array}{l}\text { It should be applied by any } \\
\text { SES team professional with } \\
\text { specific training in ASD and in } \\
\text { this } \\
\text { instrument. Respondents to } \\
\text { the instrument are the } \\
\text { parents or caregivers of the } \\
\text { child. }\end{array}$ \\
\hline & $\begin{array}{l}\text { In case of nonverbal } \\
\text { children with } 2 \frac{1}{2}-7 \\
\text { years old: Non- } \\
\text { Verbal Intelligence } \\
\text { Test SON-R } 2 \frac{1}{2}-7 a \\
\text { (LAROS et al., } \\
2013) \text {. }\end{array}$ & $\begin{array}{l}\text { Evaluates the intellectual functioning of } \\
\text { children between the ages of } \\
2 \frac{1}{2} \text { and } 7 \text {. The test does not require } \\
\text { instructions or verbal responses that } \\
\text { are often compromised in children } \\
\text { with ASD. It has four subtests: mosaics, } \\
\text { categories, puzzles, analogies, } \\
\text { situations and patterns. Offers scores } \\
\text { indicative of reasoning and execution } \\
\text { skills. }\end{array}$ & $\begin{array}{l}\text { Must be applied by a } \\
\text { Psychologist. }\end{array}$ \\
\hline
\end{tabular}


Therefore, in accordance with the flowcharts, elementary school students up to the 5th grade who meet the requirements described above are referred to the SES team, who will carry out the relevant specialized assessment. As described in Chart 1 and in the flowcharts in Figures 1 and 2, these actions are: a) Students with suspected ASD will be evaluated by a psychologist using WASI or SON-R $2 \frac{1}{2}-7 \mathrm{a}, \mathrm{ASQ}, \mathrm{BPM}-\mathrm{P}$ and application of the ASD Checklist with the caregiver (the details in relation to the respondents to these instruments are described in Chart 1); b) Students with suspected ID will be evaluated by a psychologist using WASI, BPM-P and application of the ID Checklist with the caregiver (the details in relation to the respondents to these instruments are described in Chart 1).

The main advantage of using this model is that data resulting from the evaluations are stored using BPMS in a data repository, allowing the generation of reports containing all the descriptive results of the evaluation. The report will allow the visualization of the results of all evaluations, namely, the ASD or ID indicators checklist, the neuropsychological assessment (WASI or SON-R $2 \frac{1}{2-7}-7$ ), the emotional and behavioral assessments (BPM-T and BPM-P) and the evaluation of ASD signs using the ASQ. The results from instruments that are restricted because they contain intellectual property will be presented in the reports only in relation to the total score or the score of the scales, depending on the instrument (WASI or SON-R $2 \frac{1}{2}-7 \mathrm{a}, \mathrm{BPM}-\mathrm{T}$ and BPM-P and ASQ).

The computer system proposed in the study based on BPMS will allow the modeling of all activities and tasks and, at the same time, the storage of data about the student. This strategy will make it possible to visualize in real time the actions of all the professionals that work with the student and, over the years, will generate a database of special education target students. These databases will enable more complex analyses through the application of embedded artificial intelligence algorithms for data mining tasks (CHIAVEGATTO FILHO, 2015; SILVA, PERES \& BOSCARIOLI, 2016), a promising solution in various areas of knowledge and public sectors (MAYER-SCHÖNBERGER \& CUCKIER, 2013).

In addition, the use of this type of model adopting all the steps of the flowcharts may significantly decrease the backlog of students waiting for assessments to clarify their difficulties, some of them with a great impact on adaptive functioning and opportunities for learning academic skills (CARDOSO et al., 2012; ROSSATO \& LEONARDO, 2012; ENRICONE \& SALLES, 2012; CARNEIRO \& COUTINHO, 2015; PALERMO et al., 2015). Unlike Brazil, other countries, such as The United States, include in their government policies the use of assessment technologies and preventive intervention measures for various correlates of behavioral problems and cognitive functioning deficits in children with signs of neurodevelopmental disorders (ROTHOLZ et al., 2013).

The study presents a process model for teachers and educational managers that uses a computer system to assist them in the collection, storage, and analysis of data, as well as enabling them to make decisions in real time to identify students with suspected

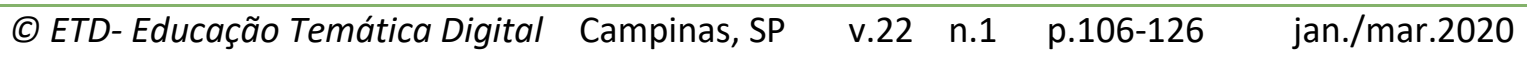


neurodevelopmental disorders consistent with ID and ASD. This model presents a real possibility for an intersectoral approach, with education and health services working together to identify students with suspected ID and ASD. The data required for the development of models and decision-making processes for the identification of complaints will be derivedfrom cognitive and emotional-behavioral evaluations. Using these assessments, teachers, SES teams and educational managers can develop the skills to produce an effective assessment for identifying students with suspected ID or ASD. They can also become proficient in the use of standardized assessment tools and computerized technologies to assist them in decision making in elementary education, both for the identification of students suspected to have these conditions and for their referral to other public services such as health.

\section{CONCLUSION}

In Brazil, the public health system (SUS), through the Primary Health Care Units is the gateway for the evaluation and diagnosis of individuals with suspected developmental disorders. In general, these referrals, often generated in the educational system, lack pertinent information because the observations about student performance are not systematized. Structured reports with objective observations will facilitate reference and counter-reference procedures between education and health. This study shows a structured model that meets these procedures.

Once the suspicion of ASD or ID in an elementary school student has been raised, following the process model presented in this study optimizes the further definition of the problem of the student in the minimum time so that they can receive the appropriate intervention. The system presented here and the actions detailed in the flowchart for each disorder function as a tool that makes it possible for teachers to develop the skills and competencies required to recognize signs of ASD and ID. In addition, it provides the teacher with an appropriate set of tools to identify and make an initial evaluation of the student. Thus, the identification of signs indicative of these neurodevelopmental disorders, enables the student to receive furthermore specialized evaluations and services that correspond to their needs.

The implementation of this model in the educational system can validate the feasibility of its for other neurodevelopmental disorders. In fact, this model has already been developed by the authors of this study for use in Attention Deficit Hyperactivity Disorder (ADHD) and Specific Learning Disorder (SLD). A general model covering the four disorders (ASD, ID, ADHD and SLD) is already being tested in a municipal educational system in the State of São Paulo in a research project financed by the São Paulo Research Foundation (FAPESP). In this project the flowcharts are being tested with students without complaints to compare the results with

(C) ETD-Educação Temática Digital Campinas, SP $\quad$ v.22 n.1 $\quad$ p.106-126 jan./mar.2020 
students who present suspected ASD and ID, as well as to identify false negative cases in order to verify the specificity of the checklists that were developed.

Another important outcome is the validation of the potential for collaborative working between different sectors (education and health). Finally, the system can test the sensitivity of the checklists by comparing their results with the outcome of the health service diagnostic evaluation and verify the sensitivity indicators of the checklists.

\section{REFERENCES}

ACHENBACH, Thomas M. ; RESCORLA, Leslie A. Manual for the Aseba School-age forms \& profiles. Burlington: University of Vermont, Research Center for Children, Youth \& Families, 2001.

AMERICAN PSYCHIATRIC ASSOCIATION - APA. Manual diagnóstico e estatístico de transtornos mentais (DSM-V). 5.ed. Porto Alegre: Artes Médicas, 2014.

ARAUJO, A. K. DE; TANAKA, O. Y. Avaliação do processo de acolhimento em saúde mental na região centro-oeste do município de São Paulo: a relação entre CAPS e UBS em análise. Interface - Comunicação, Saúde, Educação, v. 16, n. 43, p. 917-928, 2012.

BORDINI, D. et al. Impact of training in autism for primary care providers: A pilot study. Revista Brasileira de Psiquiatria, v. 37, n. 1, p. 63-66, 2015.

CARDOSO, M. H.; ROMERO, A. C. L.; CAPELLINI, S. A. Alterações dos processos fonológicos e índice de gravidade entre escolares com dislexia e escolares com bom desempenho acadêmico. Revista da Sociedade Brasileira de Fonoaudiologia, v. 17, n. 3, p. 287-292, 2012.

CARNEIRO, C.; COUTINHO, L. G. Infância e adolescência: como chegam as queixas escolares à saúde mental? Educar em Revista, n. 56, p. 181-192, 2015.

DENCKLA, C. A. et al. Psychometric properties of the Ndetei-Othieno-Kathuku (NOK) Scale: a mental health assessment tool for an African setting. Journal of Child and Adolescent Mental Health, v. 29, n. 1, p. 39-49, 2017.

ENRICONE, J. R. B.; SALLES, J. F. DE. Relação entre variáveis psicossociais familiares e desempenho em leitura/escrita em crianças. Psicologia Escolar e Educacional, v. 15, n. 2, p. 199-210, 2012.

FARIA, K. T. et al. Atitudes e práticas pedagógicas de inclusão para o aluno com autismo. Revista Educação Especial, v. 31, n. 61, p. 353, 2018.

KARAM, S. M. et al. Genetic causes of intellectual disability in a birth cohort: a populationbased study. American Journal of Medical Genetics, Part A, v. 167, n. 6, p. 1204-1214, 2015.

LAKHAN, R.; MAWSON, A. R. Identifying children with intellectual disabilities in the tribal

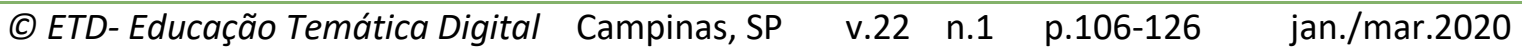


population of Barwani district in state of Madhya Pradesh, India. Journal of Applied Research in Intellectual Disabilities, v. 29, n. 3, p. 211-219, 2016.

LAROS, A.; JESUS, R. DE; KARINO, A. Validação brasileira do teste não-verbal de inteligência SON-R 21⁄2-7 [ a ] 1 , 2. Avaliação Psicológica, v. 12, n. 2, p. 233-242, 2013.

MALTA, D. C. et al. Prevalência autorreferida de deficiência no Brasil, segundo a Pesquisa Nacional de Saúde, 2013. Ciência \& Saúde Coletiva, v. 21, n. 10, p. 3253-3264, 2016.

MARTELETO, M. R. F.; PEDROMÔNICO, M. R. M. Validity of Autism Behavior Checklist (ABC): preliminary study validade do Inventário de Comportamentos Autísticos (ICA): estudo preliminar. Brazilian Journal of Psychiatry, v. 27, n. 4, p. 295-301, 2005.

MAULIK, P. K. et al. Prevalence of intellectual disability: a meta-analysis of population-based studies. Research in Developmental Disabilities, v. 32, n. 2, p. 419-436, 2011.

OLASHORE, A. A.; FRANK-HATITCHKI, B.; OGUNWOBI, O. Diagnostic profiles and predictors of treatment outcome among children and adolescents attending a national psychiatric hospital in Botswana. Child and Adolescent Psychiatry and Mental Health, v. 11, n. 1, p. 1-10, 2017.

PALERMO, G. A.; SILVA, D. B. DO N.; NOVELLINO, M. S. F. Fatores associados ao desempenho escolar: uma análise da proficiência em matemática dos alunos do $5^{\circ}$ ano do ensino fundamental da rede municipal do Rio de Janeiro. Revista Brasileira de Estudos de População, v. 31, n. 2, p. 367-394, 2015.

PAULA, C. S. et al. Identifying Autism with a Brief and Low-Cost Screening Instrument - OERA: construct validity, invariance testing, and agreement between judges. Journal of Autism and Developmental Disorders, v. 48, n. 5, p. 1780-1791, 2018.

PAULA, C. S.; BELISÁSIO FILHO, J. F.; TEIXEIRA, M. C. T. V. Estudantes de psicologia concluem a graduação com uma boa formação em autismo? Psicologia - Teoria e Prática, v. 18, n. 1, p. 206-221, 2016.

PORTOLESE, J. et al. Mapeamento dos serviços que prestam atendimento a pessoas com transtorno do espectro autista no Brasil. Cadernos de Pós-Graduação em Distúrbios do Desenvolvimento, v. 17, n. 2, 2017.

ROBERTSON, J. et al. The identification of children with, or at significant risk of , intellectual disabilities in low- and middle-income countries : a review. Journal of Applied Research in Intellectual Disabilities, v. 25, n. 2, p. 99-118, 2012.

ROSSATO, S. P. M.; LEONARDO, N. S. T. A queixa escolar na perspectiva de educadores da Educação Especial. Psicologia Escolar e Educacional, v. 16, n. 1, p. 15-24, 2012.

ROTHOLZ, D. A.; MOSELEY, C. R.; CARLSON, K. B. State policies and practices in behavior supports for persons with intellectual and developmental disabilities in the United States: A national survey. Intellectual and Developmental Disabilities, v. 51, n. 6, p. 443-445, 2013.

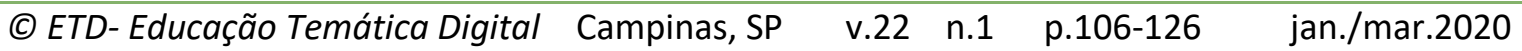


RUSSELL, G. et al. Selection bias on intellectual ability in autism research : a cross-sectional review and meta-analysis. Molecular Autism, p. 1-10, 2019.

SURIANO, R. Um modelo de transferência de tecnologias para a educação básica para avaliação de alunos com sinais do transtorno do espectro autista e deficiência intelectual. 2018. Dissertação (Mestrado em Distúrbios do Desenvolvimento) - Universidade Presbiteriana Mackenzie, São Paulo, 2018.

TEIXEIRA, M. C. T. V. et al. Mismatch between diagnostic reports and special educational needs classification in a public educational system TT - Descompasso entre os registros diagnósticos e a classificação de necessidade educacional especial em uma rede municipal de educação. Arquivos de Neuro-Psiquiatria, v. 75, n. 4, p. 244-247, 2017.

YATES, D. B. et al. Apresentação da Escala de Inteligência Wechsler Abreviada (WASI). Avaliação Psicológica, v. 5, n. 2, p. 227-233, 2006.

ZANON, R. B.; BACKES, B.; BOSA, C. A. Identificação dos primeiros sintomas do autismo pelos pais. Psicologia: Teoria e Pesquisa, v. 30, n. 1, p. 25-33, 2014.

\section{Manuscript translated and revised by:}

Paul D. Ferri.

E-mail: ferri.davis.consultoria@gmail.com. 
Appendix A. Suspected Autism Spectrum Disorder screening checklist.

\section{CHECKLIST OF INDICATORS FOR VERIFICATION OF AUTISTIC SPECTRUM DISORDER SIGNS}

\begin{tabular}{|c|c|}
\hline Teacher instruction & Parent instruction \\
\hline $\begin{array}{l}\text { Dear teacher, } \\
\text { Below is a list of behaviors that describe children } \\
\text { with Autism signs. Each item must be answered } \\
\text { according to your current observation or within } \\
\text { the last } 3 \text { months. Please circle "Never or } \\
\text { Rarely", "Sometimes", "Often" or "Very often". } \\
\text { Please answer all items as well as you can, even } \\
\text { if some do not seem to apply to the student. }\end{array}$ & $\begin{array}{l}\text { Dear parents, } \\
\text { Below is a list of behaviors that describe children } \\
\text { with Autism signs. Each item must be answered } \\
\text { according to your current observation or within } \\
\text { the last } 3 \text { months. Please circle "Never or Rarely", } \\
\text { "Sometimes", "Often" or "Very often". Please } \\
\text { answer all items as well as you can, even if some } \\
\text { do not seem to apply to the child. }\end{array}$ \\
\hline
\end{tabular}

\section{Domain A}

\begin{tabular}{|c|c|c|c|c|}
\hline \multicolumn{5}{|c|}{ "Never or Rarely" ( $\mathrm{N}$ or R), "Sometimes" (S), "Often" (O) or "Very often (VO) } \\
\hline Indicators & $\mathbf{N}$ or $\mathbf{R}$ & $\mathbf{S}$ & 0 & vo \\
\hline \multicolumn{5}{|l|}{$\begin{array}{l}\text { Difficulties in communication and social interaction } \\
\text { with other people in the school (not explained only by } \\
\text { shyness). For example, inappropriate approaches to } \\
\text { establishing social interactions and communicating or } \\
\text { speaking only about subjects of their own interest } \\
\text { during these interactions. }\end{array}$} \\
\hline \multicolumn{5}{|l|}{$\begin{array}{l}\text { Difficulties to establish a conversation with peers of } \\
\text { the same age and to respect the subject's and speech } \\
\text { shift. }\end{array}$} \\
\hline \multicolumn{5}{|l|}{$\begin{array}{l}\text { Difficulties to share interests, for example, do not } \\
\text { show interest in the subject of others. }\end{array}$} \\
\hline \multicolumn{5}{|l|}{$\begin{array}{l}\text { Difficulties to put itself in the other's place and } \\
\text { understand the emotions or affections, for example, } \\
\text { the student is not moved by the emotion and feelings } \\
\text { of the classmate. }\end{array}$} \\
\hline \multicolumn{5}{|l|}{$\begin{array}{l}\text { Difficulty initiating or responding to social } \\
\text { interactions, for example, not offering group play or } \\
\text { not reacting to invitations to play (not explained only } \\
\text { by shyness). }\end{array}$} \\
\hline \multicolumn{5}{|l|}{$\begin{array}{l}\text { Difficulties in understanding gestures and body } \\
\text { language during social interactions, for example, a } \\
\text { nod, frowning, a sign of "ok". }\end{array}$} \\
\hline \multicolumn{5}{|l|}{$\begin{array}{l}\text { Difficulties in establishing or maintaining eye contact } \\
\text { during social interactions. }\end{array}$} \\
\hline $\begin{array}{l}\text { The child's emotions do not match with situations, for } \\
\text { example, showing an expression of sadness or anger } \\
\text { in situations that do not demand these types of facial } \\
\text { expressions, or maintaining a constant smile on the } \\
\text { face without suitability to the context. }\end{array}$ & & & & \\
\hline
\end{tabular}


Difficulties adjusting behavior to different social contexts, for example, too quiet or talking non stopping about a subject without realizing that others do not want to hear anymore.

Difficulty participating and engaging in imaginative play, for example, police and thief and make-believe play.

Difficulties in making friends or being interested in peers of the same age (not explained only by shyness).

\section{Domain B}

\begin{tabular}{|l|l|l|l|l|}
\hline \multicolumn{1}{|c|}{ "Never or Rarely" (N or R), "Sometimes" (S), "Often" (O) or "Very often (VO) } \\
\hline \multicolumn{1}{|c|}{ Indicators } & N or R & S & O & V O \\
\hline $\begin{array}{l}\text { Shows repetitive motor movements, for example, to } \\
\text { waving hands, rocking parts and / or body, rolling } \\
\text { head. }\end{array}$ & & & & \\
\hline Shows immediate repetition of words or phrases. & & & & \\
\hline $\begin{array}{l}\text { Shows exact repetition of previously heard phrases in } \\
\text { other contexts, for example, movie character phrases, } \\
\text { cartoons or phrases spoken by other people. }\end{array}$ & & & & \\
\hline $\begin{array}{l}\text { Shows insistence on the same things, for example, } \\
\text { wanting to spend a lot of time engaged in the same } \\
\text { task; repetitive use of objects; line up toys or spin } \\
\text { objects; greeting rituals, asking repetitive questions. }\end{array}$ & & & & \\
\hline $\begin{array}{l}\text { Inflexible to routines, for example, need to make the } \\
\text { same path between the classroom and the } \\
\text { playground. }\end{array}$ & & & & \\
\hline $\begin{array}{l}\text { Shows extreme suffering crying or with self-agressive } \\
\text { behaviors, regarding changes of routines or difficulties } \\
\text { with transitions from one routine to another, for } \\
\text { example, change of teacher in the classroom. }\end{array}$ & & & & \\
\hline $\begin{array}{l}\text { Strict patterns of thinking, for example, insist on the } \\
\text { same ideas and think / talk about the same subjects. }\end{array}$ & & & & \\
\hline $\begin{array}{l}\text { Fixed and highly restricted interests that are abnormal } \\
\text { in intensity or focus compared to other children, for } \\
\text { example, like dinosaurs and just talk about it, has a } \\
\text { collection on the subject, etc. }\end{array}$ & & & & \\
\hline $\begin{array}{l}\text { Apparent insensitivity to pain or temperature } \\
\text { changes. }\end{array}$ & & & & \\
\hline $\begin{array}{l}\text { Shows strange reactions to the environment, for } \\
\text { example, sniffing or touching objects, fascination or } \\
\text { dislike of lights, sounds or movements. }\end{array}$ & & & & \\
\hline & & & & \\
\hline
\end{tabular}

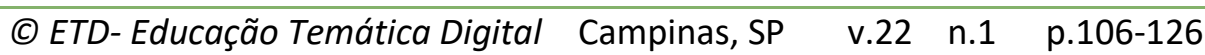


The above difficulties cause impairment in the child's adaptation to school or in relationships with classmates

Appendix B. Suspected Intellectual Disability screening checklist.

\section{CHECKLIST OF INDICATORS FOR VERIFICATION OF INTELLECTUAL DISABILITY SIGNS}

\begin{tabular}{|l|}
\hline Teacher instruction \\
Dear teacher, \\
Below is a list of behaviors that describe children \\
with intellectual disability signs. Each item must be \\
answered according to your current observation or \\
within the last 3 months. Please circle "Never or \\
Rarely", "Sometimes", "Often" or "Very often". \\
Please answer all items as well as you can, even if \\
some do not seem to apply to the student.
\end{tabular}

\section{Parent instruction}

Dear parents,

Below is a list of behaviors that describe children with intellectual disability signs. Each item must be answered according to your current observation or within the last 3 months. Please circle "Never or Rarely", "Sometimes", "Often" or "Very often". Please answer all items as well as you can, even if some do not seem to apply to the child.

\section{Domain A}

\begin{tabular}{|l|l|l|l|l|}
\hline \multicolumn{2}{|c|}{ Indicators } & Never or Rarely" (N or R), "Sometimes" (S), "Often" (O) or "Very often (VO) \\
\hline Compared with other children of the same age: & & S & O & V O \\
\hline $\begin{array}{l}\text { Difficulties in reasoning skills, for example, do not } \\
\text { identify similarities or differences between two } \\
\text { figures or two concepts. }\end{array}$ & & & & \\
\hline $\begin{array}{l}\text { Difficulties in solving both academic and daily } \\
\text { problems, for example, not being able to request } \\
\text { a colleague or teacher for help when they have a } \\
\text { doubt about a school activity or not knowing how } \\
\text { to request to go to the bathroom, if needed. }\end{array}$ & & & & \\
\hline $\begin{array}{l}\text { Difficulties in planning activities, for example, are } \\
\text { unable to prepare and prior arrange a set of } \\
\text { actions to put into practice a clipping and collage } \\
\text { activity on a determining subject. }\end{array}$ & & & & \\
\hline $\begin{array}{l}\text { Difficulties of abstract thinking, for example, } \\
\text { difficulty in playing with imaginary situations, } \\
\text { giving voice to inanimate objects or defining a } \\
\text { certain concept of school subjects. }\end{array}$ & & & & \\
\hline $\begin{array}{l}\text { Difficulties in the ability to make judgments about } \\
\text { how something was done (right or wrong), both by } \\
\text { himself and a colleague. }\end{array}$ & & & & \\
\hline $\begin{array}{l}\text { Difficulties in learning academic content involving } \\
\text { reading and writing. }\end{array}$ & & & & \\
\hline $\begin{array}{l}\text { Difficulties in learning academic content involving } \\
\text { mathematics. }\end{array}$ & & & & \\
\hline
\end{tabular}


Difficulties to learn from day-to-day experiences in living together with classmates.

\section{Domain B}

"Never or Rarely" (N or R), "Sometimes" (S), "Often" (O) or "Very often (VO)

\begin{tabular}{|c|c|c|c|c|}
\hline Indicators & \multirow[t]{2}{*}{$\mathbf{N}$ or $\mathbf{R}$} & \multirow[t]{2}{*}{$\mathbf{S}$} & \multirow[t]{2}{*}{0} & \multirow[t]{2}{*}{ vo } \\
\hline Compared with other children of the same age: & & & & \\
\hline $\begin{array}{l}\text { Shows itself to be immature in social relationships, } \\
\text { for example, does things that younger children do. }\end{array}$ & & & & \\
\hline $\begin{array}{l}\text { Has difficulty perceiving social cues from peers, for } \\
\text { example, difficulty in noticing when a colleague is } \\
\text { angry or sad. }\end{array}$ & & & & \\
\hline $\begin{array}{l}\text { Communication and conversation are concrete } \\
\text { and immature for what is expected for the age, for } \\
\text { example, if compared to colleagues uses fewer } \\
\text { words and simpler sentences with little } \\
\text { abstraction. }\end{array}$ & & & & \\
\hline $\begin{array}{l}\text { Shows difficulties regulating emotion in relation to } \\
\text { other children or in relation to peers, for example, } \\
\text { not being able to adequately express their } \\
\text { emotions, desires and frustration tolerance. }\end{array}$ & & & & \\
\hline $\begin{array}{l}\text { Has a limited understanding of risk in social } \\
\text { situations, for example, has no idea of danger, } \\
\text { talks to strangers, walks with people who can } \\
\text { bring him problems. }\end{array}$ & & & & \\
\hline $\begin{array}{l}\text { The social judgment is immature for the age, being } \\
\text { able to be manipulated by the others (gullibility). }\end{array}$ & & & & \\
\hline $\begin{array}{l}\text { Difficulties to perform activities of daily living that } \\
\text { interfere with independence. }\end{array}$ & & & & \\
\hline $\begin{array}{l}\text { Difficulties to show responsibility in the social life } \\
\text { expected for the age, for example, respect lines, } \\
\text { fulfill their work when the task is in a group. }\end{array}$ & & & & \\
\hline
\end{tabular}

